\title{
Management of chronic sensitization, from drugs to physical therapy
}

\author{
Nathalie Roussel', Mira Meeus, Liesbeth Daenen, Jessica Van Oosterwijck, Patrick Cras, Jo Nijs \\ From The European Headache and Migraine Trust International Congress \\ London, UK. 20-23 September 2012
}

Over the past decades, scientific understanding of unexplained chronic pain disorders has increased substantially. Several chronic musculoskeletal pain disorders may be explained by alterations in central nervous system processing. More specifically, the responsiveness of central neurons to input from unimodal and polymodal receptors is augmented, resulting in a pathophysiological state corresponding to central sensitization, characterized by generalized or widespread hypersensitivity. Central sensitization encompasses altered sensory processing in the brain, impaired functioning of top-down anti-nociceptive mechanisms, and (over)activation of top-down and bottomup pain facilitatory pathways which augment nociceptive transmission. Importantly, a different 'pain signature' arises in the brain of those with chronic musculoskeletal pain and central sensitization.

Given the increasing evidence supporting the clinical significance of central sensitization in those in a wide variety of disorders, including chronic whiplash associated disorders, chronic tension-type headache and migraine among others, the awarenes`s is growing that desensitising the central nervous system should be a treatment target in these patients. Besides pharmacological options, rehabilitation (consisting of pain physiology education, stress management and exercise therapy) and neurotechnology options (e.g. Transcranial magnetic stimulation, TENS, _virtual reality) offer interesting perspectives.

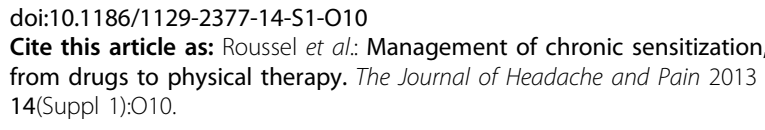

Department of Rehabilitation Sciences and Musculoskeletal Physiotherapy, Artesis College, Antwerp, Belgium
Submit your manuscript to a SpringerOpen ${ }^{\circ}$ journal and benefit from:

- Convenient online submission

- Rigorous peer review

- Immediate publication on acceptance

- Open access: articles freely available online

- High visibility within the field

- Retaining the copyright to your article
SpringerOpen $^{\odot}$

(c) 2013 Roussel et al; licensee Springer. This is an Open Access article distributed under the terms of the Creative Commons Attribution License (http://creativecommons.org/licenses/by/2.0), which permits unrestricted use, distribution, and reproduction in any medium, provided the original work is properly cited. 